\title{
Arastırma Makalesi
}

\section{Lise Öğrencilerinin Çizimlerinden “Ödev” Kavramına ilişkin Düşüncelerinin Analizi*}

\author{
Gülay EKİCi ${ }^{1}$ (D) Burcu TURGUT ${ }^{2}$ (D) Hasan AKDENIZ ${ }^{3}$
}

\begin{abstract}
$\ddot{\mathbf{O ̈ z}}$
Bu çalışmanın amacı, lise öğrencilerinin çizimlerinden ödev kavramına ilişkin düşüncelerini analiz etmektir. Çalışma nitel araştırma modeli kapsamında durum çalışması deseni kullanılarak hazırlanmıştır. Amaçlı çalışma grubu seçilen araştırma toplam 225 lise öğrencisinin katılımıyla hazırlanmıştır. Verilerin toplanmasında çizme-yazma tekniği kullanılmıştır. $\mathrm{Bu}$ süreçte verilerin analizinde NVivo9.3 programından yararlanılarak içerik analizi yapılmıştır. Çalışmada öğrencilerin oldukça orijinal çizimler yaptıkları ve çok fazla yazıyla açıklama ihtiyacı duymadıkları belirlenmiştir. Bu kapsamda lise öğrencilerinin ödev kavramıyla ilgili düşünceleri çizme-yazma tekniğiyle toplam 6 kategori kapsamında analiz edilmiştir. Bu kategoriler şu şekilde sıralanmaktadır; "Aydınlatıı1/Temizleyici/ Besleyici etkisi, Kontrol altına alıcı etkisi, Ödev yapabilmenin gerekleri, Sürekli çalışma gerektirmesi, Paylaşım gerektirmesi ve Oyunu hatırlatması" kategorisine ait çok fazla görüş belirttikleri tespit edilmiş̧ir. Bu kapsamda ise ödev yapabilmek için geç saatlere kadar çalışmak gerektiği, masa başında oturmak gerektiği ve ödev yapmanın kişiyi kontrol altında tuttuğu belirtilmektedir. Ayrıca öğrenciler çizimlerinde ve yazımlarında ödevin öğrencilerin akademik gelişiminde etkisi olduğu, paylaşma duygusunu geliştirdiği, bir konuyla ilgili teknolojiyi de kullanarak geniş kapsamlı bilgi elde edebileceklerini ifade ettikleri belirlenmiştir. Sonuç olarak; öğrencilerin ödeve yönelik hem olumlu hem de olumsuz düşüncelere sahip oldukları belirlenmiştir.
\end{abstract}

Anahtar kelimeler: Ödev, çizme-yazma tekniği, içerik analizi

\section{$\underline{\text { Research Article }}$}

\section{Analysis of High School Students' Views on the Concept of "Homework" from their Drawings}

\begin{abstract}
The purpose of this study is to analyze the views of high school students on the concept of "homework" from their drawings. The study was prepared by using a case study design within the qualitative research model. Purposive study group selected research was prepared with the participation of 225 high school students in total. Drawing-writing technique was used to collect the data. In this process, content analysis was made by using NVivo 9.3 program in the analysis of the data. In the study, it was determined that the students made quite original drawings and did not need to explain with too much text. In this context, the views of high school students about the concept of homework were analyzed within a total of 6 categories with drawing-writing technique. These categories are as following; "Continuous working requirement, Enlightening/cleaner effect of the homework, Getting under control effect, Requirements for homework, Sharing requirement, Game reminder". It has been found out that students have a lot of opinions especially about the category "Continuous working requirement". In this context, it is stated that studying until late hours and sitting at the table is necessary to be able to do homework and doing homework keeps the person under control. In addition, it has been also seen that, Students expressed in their drawings and writings; the homework has an effect on the academic development of the students, it develops a sense of sharing and that they can obtain a wide range of information by using the related technology. As a result; it was determined that students have both positive and negative thoughts towards homework.
\end{abstract}

Keywords: Homework, drawing-writing technique, content analysis

\section{Gelis Tarihi: 07/07/2018 Kabul Tarihi: 16/12/2018}

* To cite this article: Ekici, G., Turgut, B. \& Akdeniz, H. (2019). Lise öğrencilerinin çizimlerinden “ödev” kavramına ilișkin düşüncelerinin analizi. International e-Journal of Educational Studies (IEJES), 3 (6), 58-69. DOI: 10.31458/iejes.441521

${ }^{I}$ Prof. Dr., Gazi University, Ankara, Turkey, gekici@gazi.edu.tr,

${ }^{2}$ Graduate Student, Gazi University, Ankara,Turkey, burcuturgut@ymail.com

${ }_{3}^{3}$ PhD Student, Gazi University, Ankara,Turkey, hasanakdeniz.gazi@gmail.com

Corresponding Author e-mail address: gekici@gazi.edu.tr 


\section{GíRIŞ}

Öğrencinin okula başlamasıyla birlikte hayatında ödev hazırlama süreci de başlamaktadır. Ödev öğrencilerin çoğunun sevmediği bir uygulama olmasına rağmen eğitim hayatının vazgeçilmezlerindendir. Ödevler hem ders içinde hem de ders dışında yapılabilecek uygulamalardan olup ilgili literatürde genelde ders dışı öğretim uygulamalarından biri olarak kabul edilmektedir (Hong \& Lee, 1999). Yapılan çalışmalarda, ödevlerin farklı yaş gruplarında farklı etkiye sahip olduğunun belirtilmesine rağmen, özellikle ilkokul çağı çocuklarının akademik başarılarına etkisinin bulunmadığını, ortaokulda kısmen etkisi olduğunu ve ev ödevlerinin daha çok lise döneminde etkili olduğunu göstermektedir (Cooper \& Valentine, 2001; Cooper, Robinson \& Patall, 2006; Rudman, 2014). Ayrıca öğretmenlerin öğrenciye ilgi göstermesinin öğrencinin verilen görevleri tamamlamada daha istekli olmasını sağlamada önemli bir faktör olduğu kaydedilmiştir (Kapıkıran \& Kıran, 1999). Ödevlerin öğretim kademeleriyle ilişkilendirilmesinin ötesinde, ödevler öğrencilerin sıkılmayacağı şekilde verilmeli ve sosyal gelişimlerini engellememelidir. Öğrencilerin kişisel özelliklerini kazanacakları dönemlerde onları eve kapatacak başka şeylere vakit ayıramayacak hale gelmelerini sağlayacak ödevlerin yararından çok zararı görülecektir (Eren \& Henderson, 2007). Ancak ilgili literatürde ödevin öğrenciye katkısının olup olmadığı, hangi okul döneminde nasıl bir katkısı olduğu, hangi ödevlerin öğrencilere daha yararlı olduğu, ödev konusunda ailenin katkısı ne olmalıdır gibi konular hala tartışılan konulardandır (Deveci, 2011; Eren \& Henderson, 2011; Froiland, 2011; Rudman, 2014). Fakat öğrencinin ödev yapmaktaki başarısının verilen ödeve, ödevin verilme sıklığına ve içeriğine, öğrencinin dersi sevip sevmemesi, ödevin sonunda ödül-ceza şeklindeki seçeneklerin olup-olmamas1, ailesinin ödevine destek verip-vermemesi, grup veya bireysel olarak yapılabilecek bir ödev olup-olmaması gibi pek çok faktöre bağlı olduğu düşünülecek olursa uzun yıllar araştırmacıların gündeminden düşmeyecek bir konu olarak algılanabilir. Ödevin etkisi ve verilip verilmemesi gerektiği konusu çok boyutlu incelenmesi gereken bir konudur. Çünkü ödevin niteliği, öğrenci özellikleri, veli özellikleri, öğretmen özellikleri, okul nitelikleri gibi pek çok faktörün etkisinde olan bir uygulamadır.

Ödevin öğrenciler üzerindeki etkisinin olduğu noktasından hareketle özellikle lise ögrencilerinin ödev konusundaki düşüncelerinin belirlenmesi oldukça önemlidir. Ödev konusunda farklı katılımcı gruplarıyla hazırlanmış olan pek çok araştırmaya rastlanmaktadır. Bu araştırmaların ilkokul, ortaokul ve lise öğrencilerinin katılımıyla yapılmış olduğu belirlenirken (Gedik, Altıntaş \& Kaya, 2011; Sarıözz, 2011; Benli \& Sarıkaya, 2013; Deveci, Önder \& Çepni, 2013; Gedik \& Orhan; 2013; Ekici \& Akdeniz, 2018) lise öğrencilerinin katılımıyla yapılmış olan araştırmanın yetersiz olduğu ve ödev konusunda öğrencilerin görüşlerinin çizme-yazma tekniğiyle belirlendiği herhangi bir çalışmanın olmadığı belirlenmiştir. Bu nedenle, bu araştırma sonuçlarının literatüre dikkat çekici ve farklı bir bakış açısı kazandıracak değerli bilgiler sunacağı umulmaktadır. Ayrıca öğrencilerin çizme-yazma tekniğini kullanarak ödev konusundaki düşüncelerini açıklarken oldukça fazla metaforlardan yararlandıkları ve ödev konusundaki düşüncelerini açıklarken benzetmeler yaptıkları belirlenmiştir. $\mathrm{Bu}$ sonuç çalışmaya özel bir nitelik kazandırmakta olup öğrencilerin konuya zengin bakış açılarını ifade etmektedir. Konuyla ilgili öğrencilerin katılımıyla yapılan çalışmaların yanında, velilerin öğrenci ödevleri konusundaki görüşlerinin değerlendirildiği (Scot-Jones, 1995; Duru \& Çöğmen, 2017) ve öğretmenlerin öğrenci ödevleri konusundaki görüşlerinin değerlendirildiği (Turanl1, 2007; Ersoy \& Anagün, 2009; Duban, 2016) araştırmaların genelde nicel modelde hazırlanmış olan çalışmalar olduğu belirlenirken bu araştırmanın nitel modelde hazırlanmış bir çalışma olması da diğer çalışmalardan yöntemsel olarak farklılı̆̆ını ifade etmektedir.

\subsection{Araştırmanın Amacı}

$\mathrm{Bu}$ çalışmanın amacı, lise öğrencilerinin çizimlerinden ödev kavramına ilişkin düşüncelerini analiz etmektir. 


\section{YÖNTEM}

\subsection{Araştırmanın Modeli ve Deseni}

$\mathrm{Bu}$ araştırmada, nitel araştırma modeli kapsamında durum çalışması deseni kullanılmıştır. Durum çalışması, bir olguyu bulunduğu doğal gerçek yaşam çerçevesi içinde belirleyen, durumları çok yönlü, sistemli ve derinlemesine inceleyen oldukça kapsamlı veriler sağlayan bir araştırma desenidir (McMillan, 2000; Yin 2003). Durum çalışmasında verilerin olabildiğince ayrıntılı, doğrudan ve mümkün olduğunca katılımcıların ifadeleriyle (ki bu çalışmada çizimleriyle de veriler desteklenmiştir) desteklenerek sunulması oldukça önemlidir (Patton, 1990; Punch, 2005). Bu çalışmada da veriler mümkün olduğunca detaylı analiz edilmiş, uygun bölümlerde hem çizimlerden hem de yazımlardan örnekler verilmiş ve çalışmanın geçerlik ve güvenirliği yönünde de gerekli literatür desteği sağlanmıştır.

\section{2. Çalışma Grubu}

Araştırmanın çalışma grubunu Ankara'da bir lisenin farklı sınıflarında kayıtlı toplam 225 öğrenci oluşturmuştur. Öğrencilerin seçiminde çalışmaya gönüllü katılmak istemek, araştırmacıların ulaşabilirliği, mümkün olduğunca sosyal ve fen alanlarından farklı alanlarda kayıtlı öğrencilerin katılımı sağlanarak amaçlı çalışma grubu seçiminde karşılaşılabilecek problemlerin (Knight ve diğ., 2013) mümkün olduğunca araştırmadaki etkisinin azaltılması sağlanmaya çalışılmıştır.

\subsection{Veri Toplama Aracı}

Araştırma verileri çizme-yazma tekniğiyle toplanmıştır. Bu teknik son y1llarda oldukça fazla kullanılmakta olup, sadece çizim tekniği olarak ve ya çizme-yazma tekniği olarak birlikte kullanılmaktadır (Kalvaitis \& Monhardt, 2012; Kalaycı, 2017; Kaya, 2017; Baysal, Apak-Tezcan \& Araç, 2018). Bu teknik kavramlarla ilgili gizli kalmış düşünce, anlama, tutum ve bilişsel yapıyla ilgili görsel imajı ortaya çıkarmayı amaçlayan doğal ve yüksek nitelikli veriler elde edilmesi açısından oldukça yararlıdır. Çalışmada katılımcıların "ÖDEV kavramıyla ilgili düşündüklerinizi şekille çizerek ve yazarak anlatınız?” sorusuna görüşlerini detaylıca ifade etmeleri istenmiştir. Şekil 1'de çizmeyazma tekniğine ait örnekler verilmiştir. Bu kapsamda K72 ve K152 numaralı katılımcıların kâğıtları örnek olarak kullanılmıştır.

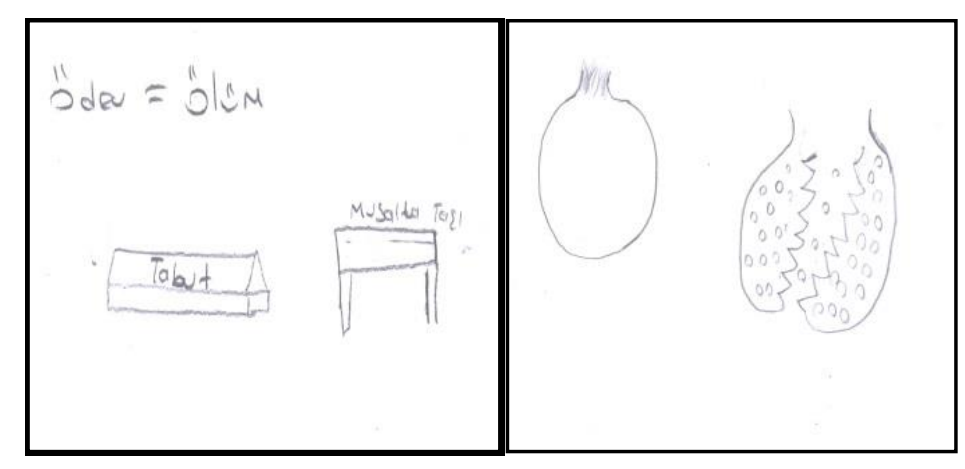

Şekil 1. Çizme-yazma tekniğine göre hazırlanmış örnekler (K72 ve K152)

\subsection{Verilerin Analizi}

Verilerin analizine başlamak için öncelikle öğrencilerin cevap kâğıtları 1'den 225'e kadar numaralandırılmıştır. Bu çalışmada sosyal alanlardaki verilerin değerlendirilmesinde çok fazla kullanılan içerik analizi yöntemi kullanılmıştır. İçerik analizinde temel amaç, verileri açıklayabilecek 
kavramlara ve ilişkilere ulaşmaktır. Birbirine benzeyen veriler belirli kavramlar ve kategoriler çerçevesinde bir araya getirilerek okuyucunun anlayabileceği biçimde düzenlenerek yorumlanır (Wimmer \& Dominick, 2000; Braun \& Clarke, 2006; Lichtman, 2010) ki burada çizimler, kavramlar, basılı dokümanlar... vb her türlü veri kaynakları kullanılır. Verilerin değerlendirilmesi ve yorumlanması süreci toplam on bir aşamada yapılmıştır. Bunlar (Ekici, 2016a,b);

(1) kâğıtların incelenme aşaması,

(2) uygun olmayan kâğıtları eleme aşaması,

(3) tekrar derleme aşaması,

(4) kâğıtların 1'den 225'e kadar numaralandırılması aşaması,

(5) çizim-yazımların incelenmesi aşaması,

(6) kategori geliştirme aşaması,

(7) çizim-yazımların kategorilere dağılımı aşaması,

(8) geçerlik ve güvenirlik aşaması,

(9) elde edilen çizim- yazımların frekanslarının hesaplanması aşaması,

(10) verilerin yorumlanması aşaması ve

(11) bilişsel modelin oluşturulma aşamasıdır (Ekici, 2016a,b).

Çizme-yazma tekniğinde ödevle ilgili çizimlere örnekler katılımcı numarası belirtilerek kategorilere göre, örneğin: K1 ve K19 olarak sunulmuştur. Bu süreçte verilerin analizinde NVivo9.3 programından yararlanılarak içerik analizi yapılmıştır.

\subsection{Geçerlik ve Güvenirlik Çalışması}

Araştırma sonuçlarının geçerliğini sağlamak amacıyla bazı düzenlemeler yapılmıştır. $\mathrm{Bu}$ kapsamda;

(1) Verilerin kodlanması ve veri analiz süreci kapsamında kavramsal kategoriye nasıl ulaşıldığıyla ilgili yapılanlar detaylı bir şekilde açıklanmıştır (Daymon \& Holloway, 2003; Hruschka ve di.̆., 2004),

(2) Araştırmada elde edilen kategorilerin her biri için öğrencilerin görüşlerinden örneklere yer verilmiştir (Wiersma \& Jurs, 2005) ve

(3) Yorumlarda ilgili araştırmalar arası tutarlı1ık sağlanmaya çalışılmıştır. Araştırmanın güvenirliğini sağlamak için ise, veri analizinin güvenirliği; [Görüş birliği / (Görüş birliği + Görüş ayrılığı) x 100] formülü kullanılarak hesaplanmıştır (Miles \& Huberman, 1994). Kodlayıcılar arasındaki ortalama güvenirlik \% 96 olarak bulunmuştur (Ekici, 2016a,b).

\section{BULGULAR}

Bu bölümde veriler analiz edilerek uygun tablolar şeklinde sunulmuştur. Bu kapsamda çizimler ve yazımlar ayrı ayrı değerlendirilerek verilmiştir.

Tablo 1. Ödev kavramıyla ilgili çizme-yazma tekniğiyle elde edilen kategori ve kodlara ait bulguların dağılımı

\begin{tabular}{llcc}
\hline Kategoriler & Kodlar & Çizimler & Yazımlar \\
\hline & Ampul & 33 & \\
1. Aydınlatıcı/Temizleyici/ Besleyici & Güneş & 25 & 1 \\
etkisi & Şampuan & 12 & \\
& Ağaç & 9 & 4 \\
& Yemek (pırasa, lahana, 1spanak & 9 & \\
\hline
\end{tabular}


$\mathrm{vb)}$

Tuz 8

Ekmek

3

Sebze çorbası 2

Yol

Yapıştırıc1

Paket lastiği

Sepette bulunan sebze ve meyveler

Yemek

Nar

Su ve musluk

Soğan

Limon

Telefon

Türlü yemeği

Matematik dersi

Havuç turşusu

Arının çiçeklerden öz/bal

toplamas1

İlaç

Toplam $=23$ çeşit kavram

Gülen çocuk figürü

Mutsuz öğrenci yüzleri

Öğretmen

10

Sürekli kafanızı meşgul etmesi

10

Uyuyan çocuk

Zincirlenmiş insan

Meyve ve çekirdekleri

Sinif

Şaşkın bir öğrenci yüz figüre

Anne ve baba baskıs1

Hapishane

Fatura ödemek

Ödev deposu

Korkutucu

Gökyüzüne ulaşmak

Okul

Ölümle ilgili (tabut, musalla taşı vb)

Sorumluluk

İşkence

Toplam= 19 çeşit kavram 


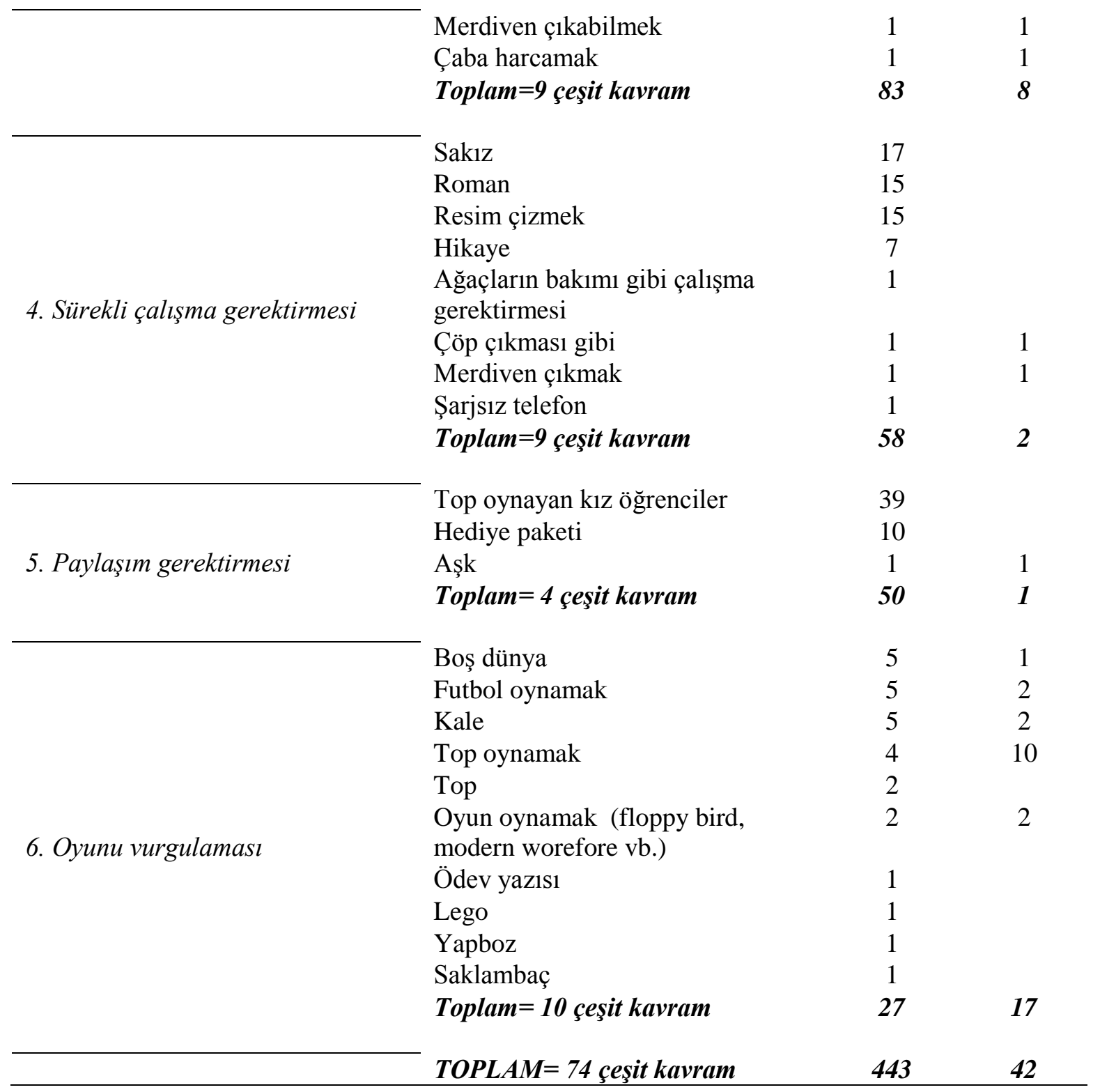

Tablo 1'de görüldüğü gibi, ödev kavramına ait çizim-yazım bulguları toplam 6 kategori altında toplanmıştır. Bu kategorilerde hem çizimlere hem de yazımlara yer verilmiştir. Bu kategoriler şu şekilde sıralanmaktadır; "Aydınlatıcı/Temizleyici/ Besleyici etkisi, Kontrol altına alıcı etkisi, Ödev yapabilmenin gerekleri, Sürekli çalışma gerektirmesi, Paylaşım gerektirmesi ve Oyunu hatırlatması"dır.

"Aydınlatıcı/Temizleyici/ Besleyici etkisi” kategorisinde toplam 23 çeşit kavram belirtilmiş olup 120 çizimle tekrar edildiği ve bu konuda 8 yazım ifade edildiği belirlenmiştir.

"Kontrol altına alıcı etkisi" kategorisinde toplam 19 çeşit kavram belirtilmiş olup 105 çizimle tekrar edildiği ve bu konuda 6 yazım ifade edildiği belirlenmiştir. "Ödev yapabilmenin gerekleri" kategorisinde toplam 9 çeşit kavram belirtilmiş olup 83 çizimle tekrar edildiği ve bu konuda 8 yazım ifade edildiği belirlenmiştir. "Sürekli çalışma gerektirmesi" kategorisinde toplam 9 çeşit kavram belirtilmiş olup 58 çizimle tekrar edildiği ve bu konuda 2 yazım ifade edildiği belirlenmiştir. "Paylaşım gerektirmesi" kategorisinde toplam 4 çeşit kavram belirtilmiş olup 50 çizimle tekrar edildiği ve bu konuda 1 yazım ifade edildiği belirlenmiştir. "Oyunu hatırlatması" kategorisinde toplam 10 çeşit kavram belirtilmiş olup 27 çizimle tekrar edildiği ve bu konuda 17 yazım ifade edildiği belirlenmiştir. 
Çizme-yazma tekniğiyle "Aydınlatıcı/Temizleyici/ Besleyici etkisi” kategorisi baskın kategori olarak ortaya çıkmıştır. Bu kategoride en fazla Ampul, Güneş, Şampuan, Ăgaç, Yemek ve Tuz kavramlarının ifade edildiği görülmektedir. Öğrencilerin çizimlerinde ödev kavramına ait somut kavramlarla bilişsel yapılarını oluşturdukları belirlenmiştir. Genelde çizimlerle görüşlerini açıkladıkları ancak yazımı daha az kullandıkları belirlenmiştir. 74 kavramın 443 defa çizilmesi ve bununla ilgili 42 yazımın ifade edilmesi bu sonucun bir göstergesidir.

Tablo 2. Öğrencilerin ödev kavramıyla ilgili çizme-yazma tekniğiyle hazırladıkları cevap kâğıtlarından örneklerin kategorilere göre dağılımı

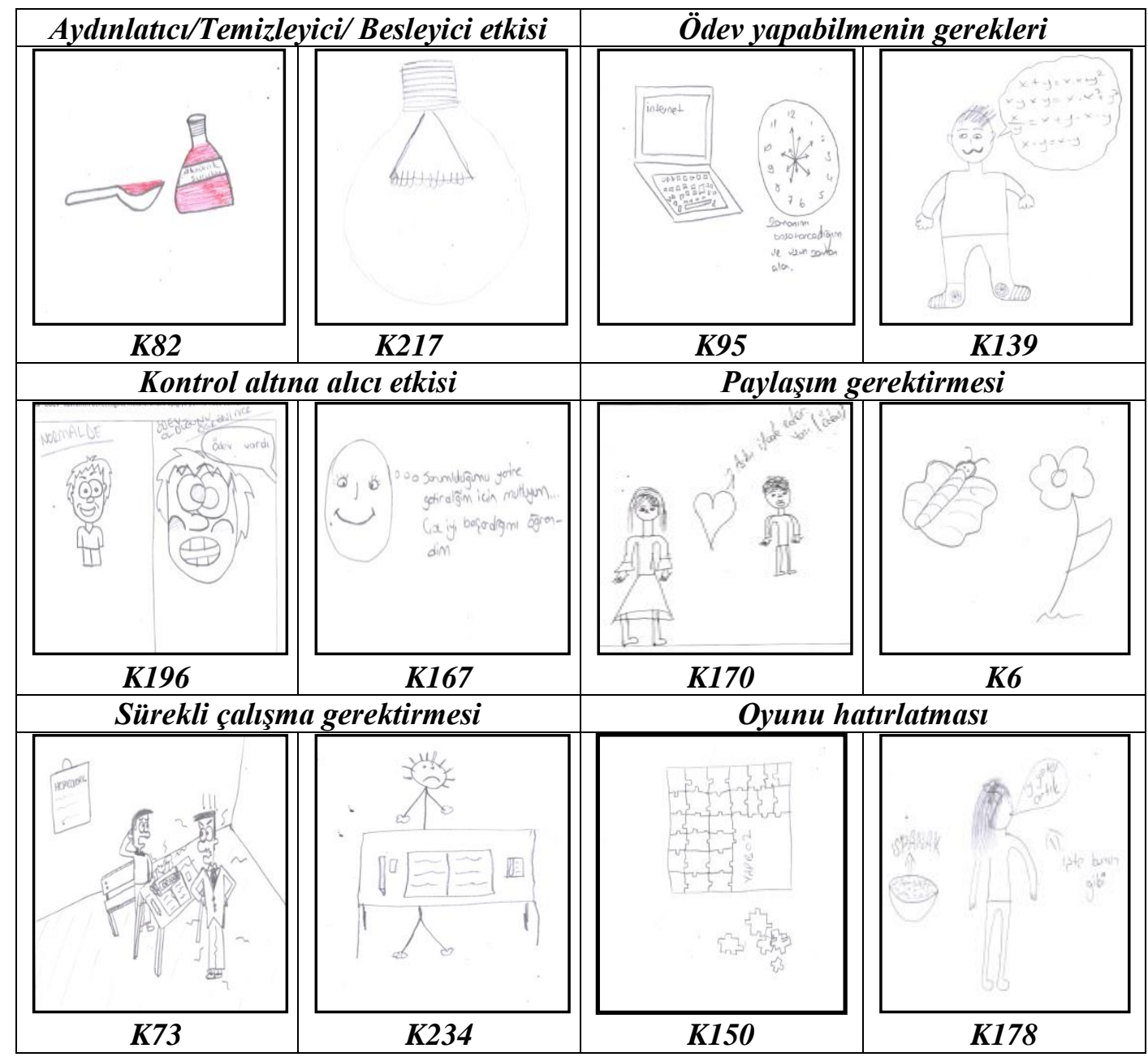

Tablo 2 incelendiğinde, öğrencilerin ödev kavramını açıklamak amacıyla oldukça anlamlı çizimler yaptıkları ve ihtiyaç duyduklarında yazıyla açıkladıkları görülmektedir. Bu çizimlerden bazılarının çok özenle hazırlandığı (örneğin; K73, K196 gibi) belirlenirken her bir çizimin ifade etmek istediği kavramsal yapıyı vurgulayabildiği söylenebilir.

\section{SONUÇ ve TARTIŞMA}

$\mathrm{Bu}$ çalışmanın amacı, lise öğrencilerinin çizimlerinden ödev kavramına ilişkin düşüncelerini analiz etmektir. Hem çizimlerle hem de yazımla öğrencilerin görüşlerini belirttikleri tespit edilmiştir. $\mathrm{Bu}$ kapsamda ödev kavramına ait çizim-yazım bulguları toplam 6 kategori altında toplanmıştır. $\mathrm{Bu}$ kategoriler şu şekilde sıralanmaktadır; "Aydınlatıcı/Temizleyici/ Besleyici etkisi, Kontrol altına alıcı etkisi, Ödev yapabilmenin gerekleri, Sürekli çalışma gerektirmesi, Paylaşım gerektirmesi ve Oyunu 
hatırlatması"dır. Belirlenen kategorilerde yer alan çizim ve yazımlar analiz edildiğinde şöyle bir dağılım ortaya çıkmaktadır;

"Aydınlatıcı/Temizleyici/ Besleyici etkisi” kategorisinde toplam 23 çeşit kavram belirtilmiş olup 120 çizimle tekrar edildiği ve bu konuda 8 yazım ifade edildiği belirlenmiştir. Bu kategoride en fazla Ampul, Güneş, Şampuan, A ̌̆aç, Yemek ve Tuz kavramlarının ifade edildiği belirlenmiştir. Bu sonuç en fazla frekans değerine sahip olan kategorinin çıkmış olması öğrencilerin her ne kadar ödevden hoşlanmıyor olsalar bile kesinlikle ödevin akademik gelişimlerine de katkı sağladığını düşündüklerini göstermektedir. Bu vurgularla ilişkili olarak kategorinin adı ödevin aydınlatıcı/temizleyici/besleyici etkisi olarak ifade edilmiştir. Ödevlerle ilgili yapılmış olan araştırmaların çoğunun öğrencilerin akademik gelişimlerine olan etkisinin belirlenmesine yönelik olarak hazırlanmış olduğu (Eren \& Handerson, 2007; Nuez ve diğ., 2015) ve iyi düzenlenmiş olan ödevlerin öğrencilerin akademik başarılarına olumlu katkı sağladığı (Rudman, 2014; Özcan \& Erktin, 2015) belirtilmektedir. Bu araştırma sonunda ödevin Aydınlatıcı/Temizleyici/ Besleyici etkisi kategorisinin en yüksek frekans değerine sahip kategori olarak belirlenmesi bu sonucu destekler niteliktedir. Çünkü öğrenciler ödevin öncelikle kendilerinin gelişimleri yönünde önemli bir uygulama olduğu düşüncesindedirler.

"Kontrol altına alıcı etkisi" kategorisinde toplam 19 çeşit kavram belirtilmiş olup 105 çizimle tekrar edildiği ve bu konuda 6 yazım ifade edildiği belirlenmiştir. Bu kategoride en fazla Gülen çocuk figürü, Mutsuz ögrenci yüzleri, Öğretmen ve Sürekli kafanızı meşgul etmesi kavramlarının ifade edildiği belirlenmiştir. Elde edilen bu sonuç literatürde farklı ölçme araçlarıyla yapılan araştırmalarda da elde edilen sonuçlarla benzerlik göstermektedir. Çünkü ev ödevlerinin çocukların akademik ilgilerini zayıflatma, fiziksel ve duygusal yorgunluğa neden olma, etkili çalışma alışkanlığını olumsuz etkileme, kopya çekme davranışına yönelme ve okula yönelik olumsuz tutum geliştirme gibi olumsuz pek çok etkilerinin olduğu belirtilmektedir (Warton, 2001; Cooper, Robinson \& Patall, 2006; Yuladır \& Doğan, 2009; Katz, Eliot \& Nova, 2014). Farklı bir bakış açısıyla Turanlı (2007) ve Patall, Cooper ve Robinson (2008) ödevler nedeniyle üzerlerinde baskı hisseden öğrencilerin aileleri ile olan sosyal ilişki ve iletişiminde problemler yaşadıklarını vurgulamaktadır. Bu araştırma sonunda da ödevlerin öğrenci üzerinde kontrol edici özelliğinin ortaya çıkmış olması, öğrencilerin bu duygusal baskı altında olduklarını hissettiklerini ortaya koymaktadır. Bu etkinin öğrenciyi çok mutlu etmeyen bir etki olduğunu söylemek mümkündür.

"Ödev yapabilmenin gerekleri" kategorisinde toplam 9 çeşit kavram belirtilmiş olup 83 çizimle tekrar edildiği ve bu konuda 8 yazım ifade edildiği belirlenmiştir. Bu kategoride en fazla Ödev malzemeleri (kitap, defter, kağıt, kalem vb), Masada ders çalışan ögrenci ve özel çalışma ortamının olması (masa, sandalye, ışı $v b$ ) kavramlarının ifade edildiği belirlenmiştir. Nitelikli ödevlerin yapılabilmesi ödev yapabilmenin gereklerini yerine getirmekle doğrudan ilişkilidir. Öncelikle ödevin, çocuğun ilgi ve merak duygusuna hitap etmesi gerekiyor ki, aksi halde hiçbir yarar sağlamamakta, özellikle her gün verilen ödevlerin, çocuklar açısından çok sıkıcı olduğu ve genellikle de ödevlerin yapılmadığı belirtilmektedir (Yıldırım, 2008). Bu noktada öğretmenlerin ödevleri verirken mutlaka öğrenci imkânlarını bilmesi gerekmektedir. Çünkü ev ödevlerinin öğrenci başarısına etkisinin yanında, etkili hazırlanmasında ailenin, ev ortamının ve çalışma atmosferinin de etkisi bulunduğu (Cooper \& Valentine, 2001: 34-45) ifade edilmektedir. Cooper'a (2007) göre ödev, öğretmenlerin öğrencilerinden okul saatleri dışında yapmalarını istedikleri görevlerdir ki bu durum öğretmenin ödev verirken öğrencinin bireysel şartlarını iyi değerlendirmesi gerektiği konusunun önemli olduğunu ifade etmektedir. Dolayısıyla ödev yapabilmenin gerektirdiği imkanlara sahip olmayan öğrenciler ödevlerini yapamadıklarında dersten, öğretmeninden ve hatta okuldan uzaklaşma eğilimi gösterebilecektir. $\mathrm{Bu}$ davranış öğrenci için olumsuzlukların habercisi olabilmektedir.

"Sürekli çalışma gerektirmesi" kategorisinde toplam 9 çeşit kavram belirtilmiş olup 58 çizimle tekrar edildiği ve bu konuda 2 yazım ifade edildiği belirlenmiştir. Bu kategoride en fazla Sakız, Roman ve Resim kavramlarının ifade edildiği belirlenmiştir. Yapılan araştırmalarda ödevin veriliş sıklığı, 
öğrencilerin ödevlerini tamamlama süresi, öğrencilerin ilgisi vb. gibi faktörlerin (Kralovec \& Buell, 2001: 39-42; Yıldırım, 2008) ödev yapmakta etkili olduğu belirtilirken, öğrencinin sürekli çalışmasını gerektirecek şekilde ödev verilmemesi oldukça önemli konulardan birini oluşturmaktadır. Çünkü öğrencilerinde çok yönlü gelişimi devam eden bireyler olduğu ve bu gelişimlerini farklı tecrübelerle tamamlayabilecekleri zamanları ödev yapmakla geçirmemelerine dikkat etmekte yarar görülmektedir.

"Paylaşım gerektirmesi" kategorisinde toplam 4 çeşit kavram belirtilmiş olup 50 çizimle tekrar edildiği ve bu konuda 1 yazım ifade edildiği belirlenmiştir. Bu kategoride en fazla Top oynayan kız öğrenciler, Hediye paketi ve Aşk kavramlarının ifade edildiği belirlenmiştir. Ödevler öğrencilerin çalışma alışkanlıklarını ve pozitif davranışlar geliştirmelerini sağlayabilecekse, aile ve okul arasındaki ilişkilerin gelişmesini sağlayacaksa (www.ed.gov./pubs/edpubs.html), öğrenciler arasındaki iletişimi güçlendirebilecekse, öğrencilerin ödev yapmaktan keyif olmalarını sağlayacaksa, ödev yapmanın mantığını kavramasını destekleyecekse ancak yararlı olacaktır. Aksi halde olumsuz rekabetlere sebep olabilecektir. Ödevlerin temel amaçlarından biri paylaşıma imkan vermesi olmalıdır. Aksi halde öğrencileri gereksiz bir hırs ve rekabet içinde okul yaşamlarında paylaşım mutluluğunu hissetmeden eğitimlerini sürdürmek zorunda bırakabiliriz.

"Oyunu hatırlatması" kategorisinde toplam 10 çeşit kavram belirtilmiş olup 27 çizimle tekrar edildiği ve bu konuda 17 yazım ifade edildiği belirlenmiştir. Bu kategoride en fazla Boş dünya, Futbol oynamak, Kale ve Top oynamak kavramlarının ifade edildiği belirlenmiştir. Oyun noktasında öğrencilerin ödev yapmayı sevdiklerini, ödev yapmaya yönelik pozitif tutum içinde olduklarını ve keyif aldıklarını düşündürmektedir. Öğrencilerin özellikle grup çalışması yapabilecekleri ödev çeşitleriyle oyun ortamında ve paylaşımı gerektirir şekilde ödev uygulamalarına yer verilebilir.

Sonuç olarak; öğrenme öğretme sürecinde öğrencilere ödevler verilmektedir. Bunlar verildiği derse göre Türkçe, matematik, fen ödevi; amacına göre hazırlık ödevi, uygulama ödevi, projeperformans ödevi; yöntemine göre araştırma ödevi, gözlem ödevi vb.; yapıldığı yere göre sınıf ödevi, ev ödevi, kütüphane ödevi vb.; süreye göre günlük, aylık, dönem ödevi, kişi sayısına göre bireysel ödev, grup ödevi, küme ödevi, sunuluş biçimine göre yazılı, sözlü, görsel ödev gibi adlandırılmaktadır (Güneş, 2014). Bu nedenle öğrenciler öğrencilik yaşamları boyunca farklı farklı ödev uygulamalarıyla karşılaşmaktadırlar. Bu farklılık ve kargaşa durumu bu araştırma sonunda elde edilen sonuçlarda da kendini göstermektedir. Öğrencilerin çizimlerinde ödev kavramına ait somut kavramlarla bilişsel yapılarını oluşturdukları belirlenmiştir. Genelde çizimlerle görüşlerini açıkladıkları ancak yazımı daha az kullandıkları belirlenmiştir. 74 kavramın 443 defa çizilmesi ve bununla ilgili 42 yazımın ifade edilmesi bu sonucun bir göstergesidir. Öğrencilerin ödevin yararlarının farkında oldukları ancak aşırı verilen ödevlerle ödeve karşı olumsuz düşüncelerinin de olduğu belirlenmiştir. Öğrencileri ödev hazırlarken ailelerinin desteklerine ihtiyaç duydukları, çok fazla vakit harcamalarını gerektiren, duygusal olarak olumsuz etkileyen, ulaşamayacakları bilgileri/ materyalleri/malzemeleri kapsayan ödevlerin verilmesi vb. ödevin beklenilen yararından çok zarar verebileceği göz ardı edilmemelidir. Belirtilen sebepler ve elde edilen sonuçlar yönünde, öğretmenlerin öğrencilerine ödev verirken dikkatli davranmalarında ve öğrenci imkanlarını değerlendirmelerinde yarar görülmektedir. Özer ve Öcal'ın (2012) hazırladıkları araştırma sonunda öğrencilerin ev ödevlerine yönelik tutumlarının farklı değişkenler açısından anlamlı farklılık göstermediği belirlenirken, Kapıkıran ve Kıran (1999) yaptıkları deneysel çalışma sonunda ödevin başarı testinde bir etki yapmadığını belirlemişlerdir. Bu sonuçlar ödeve yönelik olumlu tutumun gelişiminin farklı değişkenlerin etkisinde olduğunu ifade etmektedir. Ödev hazırlamanın bir alışkanlık ve bir kültür olduğu düşünüldüğünde öğrencilerin ilk eğitim kademelerinden itibaren ödev yapma alışkanlığı ve kültürü kazanabilmeleri yönünde etkinlikler yapmaları sağlanmalıdır. 


\section{1. Öneriler}

$\mathrm{Bu}$ araştırma görüşme gibi farklı veri toplama teknikleriyle desteklenerek, farklı branşlardaki öğrencilerin katılımıyla ve farklı derslerin ödevlerine yönelik görüşlerin belirlendiği araştırmalar hazırlanabilir. Ayrıca öğrencilerin farklı kategorilerde belirttikleri görüşlerinin sebeplerini belirlemeye yönelik, özellikle karma model ve karma modelin farklı desenlerinde düzenlenen araştırmalar hazırlanabilir. Ödevin farklı katılımcı gruplarıyla ilgili bir etkinlik olduğu düşünüldüğünde öğrenci görüşlerinin veliler ve öğretmenlerin görüşleriyle karşılaştırıldığı araştırmalar hazırlanabilir.

\section{Bilgilendirme}

Bu çalışma 27-30 Nisan 2018 tarihinde Nevşehir Hacı Bektaş Veli Üniversitesinde düzenlenen X. Uluslararası Eğitim Araştırmaları Kongresinde sunulan sözlü bildirinin genişletilmiş tam metin halidir.

\section{KAYNAKÇA}

Baysal, Z. N., Apak Tezcan, Ö., \& Araç, K. E. (2018). Perceptions of elementary school students: Experiences and dreams about the life studies course. Universal Journal of Educational Research, 6 (3), 440-454.

Benli, E., \& Sarıkaya, M. (2013). Fen ve teknoloji dersinde verilen ödevlere yönelik ilköğretim II. kademe öğrencilerinin sınıf düzeyleri ve cinsiyete göre görüşlerinin değerlendirilmesi. Kastamonu Ĕ̈itim Dergisi, 21(2), 489-502.

Braun, V., \& Clarke, V. (2006). Using thematic analysis in psychology. Qualitative Research in Psychology, 3, 77-101.

Cooper, H. (2007). The battle over homework: Common ground for administrators, teachers, and parents. Thousand Oaks, CA: Corwin Press.

Cooper, H., Robinson, J. C., \& Patall, E. A. (2006). Does homework improve academic achievement? A synthesis of research, 1987-2003. Review of Educational Research, 76 (1), 1-62.

Cooper, H., \& Valentine, J. C. (2001). Using research to answer practical questions about homework. Educational Psychologist, 36, 143-153.

Daymon, C., \& Holloway, I. (2003). Qualitative research methods in public relations and marketing communications. London: Routledge.

Deveci, İ., Önder, İ., \& Çepni, S. (2013). Parents' views regarding homeworks given in science courses. Journal of Baltic Science Education, 12 (4), 497-508.

Deveci, İ. (2011). Fen ve teknoloji dersi kapsamında ilköğretim yedinci ve sekizinci sinıflarda verilen ödevler hakkında öğrenci, ögretmen ve veli görüşleri. Yayınlanmamış yüksek lisans tezi, Sakarya Üniversitesi Eğitim Bilimleri Enstitüsü, Sakarya.

Duban, N. (2016). Sınıf öğretmenlerinin ev ödevleri hakkındaki görüşleri. International Journal of Education Technology and Scientific Researches, 1, 55-67.

Duru, S., \& Çöğmen, S. (2017). İlkokul ve ortaokul öğrencileri ile velilerin ev ödevlerine yönelik görüşleri. İlköğretim Online, 16 (1), 354-365.

Ekici, G. (2016a). Öğretmen adaylarının "bilgisayar" kavramına ilişkin metaforik algıları. Gaziantep University Journal of Social Sciences, 15(3), 755-781. 
Ekici, G. (2016b). Biyoloji öğretmeni adaylarının mikroskop kavramına ilişkin algılarının belirlenmesi: Bir metafor analizi çalışması. Ahi Evran Üniversitesi Kırşehir Eğitim Fakültesi Dergisi, 17( 1), 615-636.

Ekici, G., \& Akdeniz, H. (2018). Lise öğrencilerinin "ödev" kavramına ilişkin metaforik algılarının incelenmesi. Bayburt Eğitim Fakültesi Dergisi, 13(25), 135-162.

Eren, O., \& Henderson D. J. (2007). The impact of homework on student achievement. Econometrics Journal, 11, 326-348.

Eren, O., \& Henderson, D. J. (2011). Are we wasting our children's time by giving them more homework? Economics of Education Review, 30 (5), 950-961.

Ersoy, A., \& Anagün, Ş.S. (2009). Sınıf öğretmenlerinin fen ve teknoloji dersi ödev sürecine ilişkin görüşleri. Necati Bey Eğitim Fakültesi Elektronik Fen ve Matematik Eğitim Dergisi, 3(1), 58-79.

Froiland, J.M. (2011). Parental autonomy support and student learning goals: A preliminary examination of an intrinsic motivation intervention. Child Youth Care Forum, 40, 135-149.

Gedik, N., Altıntaş, E., \& Kaya, H. (2011). Fen ve teknoloji dersinde verilen ev ödevleri hakkındaki öğrenci görüşleri. Journal of European Education, 1(1), 6-13.

Gedik, S., \& Orhan, S. (2013). İlköğretim 6. ve 7. sınıf öğrencilerinin Türkçe dersi ödevleri hakkında görüşleri. Karadeniz Araştırmaları, 38, 135-148.

Güneş, F. (2014). Eğitimde ödev tartışmaları. Bartın Üniversitesi Eğitim Fakültesi Dergisi, 3(2), 1-25.

Hong, E., \& Lee, K. (1999). Preferred homework style and homework environment in high-versus low-achieving Chinese students. http://eric.ed.gov/ERICDocs/ data/ericdocs2sq1/content_storage_01/0000019b/80/17/a9/a2.pdf

Hruschka, D. J., Schwartz, D., St.John, D. C., Picone-Decaro, E., Jenkins, R.A., \& Carey, J. W. (2004). Reliability in coding open-ended data: Lessons learned from HIV behavioral research. Field Methods, 16 (3), 307-331.

Kalaycı，S. (2017). Fen bilgisi öğretmen adaylarının "prokaryot-ökaryot" konusundaki bilişsel yapılarının belirlenmesi. e-Uluslararası Eğitim Araştırmaları Dergisi, 8 (3), 46-64

Kalvaitis, D., \& Monhardt, R.M. (2012). The architecture of children's relationships with nature: A phenomenographic investigation seen through drawings and written narratives of elementary students. Environmental Education Research, 18 (2), 209-227.

Katz, I., Eilot, K., \& Nevo, N. (2014). “I'll do it later”: Type of motivation, self-efficacy and homework procrastination. Motivation and Emotion, 38 (1), 111-119.

Kapıkıran, Ş., \& Kıran, H. (1999). Ev ödevinin öğrencinin akademik başarısına etkisi. Pamukkale Üniversitesi Eğitim Fakültesi Dergisi, 5, 54-60.

Kaya, E. (2017). Biyoloji öğretmen adaylarının “enzim” konusundaki bilişsel yapıları (Erzurum örneği). EKEV Akademi Dergisi, 21 (72), 87-108.

Knight, S. L., Nolan, J., Lloyd, G., Arbaugh, F., Edmondson, J., \& Whitney, A. (2013). Quality teacher education research: How do we know it when we see it? Journal of Teacher Education, 64 (2), 114-116.

Kralovec, E., \& Buell, J. (2001). End homework now. Educational Leadership, 58 (7), 39-42.

Lichtman, M. (2010). Qualitative research in education. Los Angeles: Sage.

McMillan, J. H. (2000). Educational research: Fundamentals for the consumer. Newyork: Addison Wesley Longman.

Miles, M.B., \& Huberman, A. M. (1994). Qualitative data analysis. Thousand Oaks, CA: Sage. 
Nuez, J. C., Suárez N., Rosário, P., Vallejo, G., Valle, A., \& Epstein, J. L. (2015). Relationships between perceived parental involvement in homework, student homework behaviors, and academic achievement: Differences among elementary, junior high, and high school students. Metacognition Learning, 10(3), 375-406.

Özcan, Z. Ç., \& Erktin, E. (2015). Enhancing mathematics achievement of elementary school students through homework assignments enriched with metacognitive questions. Eurasia Journal of Mathematics, Science \& Technology Education, 11(6), 1415-1427.

Özer, B., \& Öcal, S. (2012). İlköğretim 4. ve 5. sınıf öğrencilerinin ev ödevlerine yönelik tutumlarının değerlendirilmesi. Dicle Üniversitesi Ziya Gökalp Eğitim Fakültesi Dergisi, 18, 1-16.

Patall, E.A., Cooper, H., \& Robinson, J.C. (2008). Parent involvement in homework: A research synthesis. Review of Educational Research, 78(4), 1039-1101.

Patton, M. Q. (1990). Qualitative evaluation and research methods. USA: Sage.

Punch, K.F. (2005). Introduction to social research-quantitative \& qualitative approaches. London: Sage.

Rudman, N. P. C. (2014). A review of homework literature as a precursor to practitioner-led doctoral research in a primary school. Research in Education, 91, 12-29.

Sarıgöz, O. (2011). Ortaöğretim öğrencilerinin kimya derslerinde verilen ev ödevleri hakkındaki düşüncelerinin değerlendirilmesi. Electronic Journal of Vocational Colleges, 1, 80-87.

Scott-Jones, D. (1995). Parent-child interactions and school achievement. In B.A. Ryan \& G.R. Adams (Eds.), The family-school connection: Theory, research, and practice (pp. 75-107). Thousand Oaks, CA: Sage.

Wiersma, W., \& Jurs, S.G. (2005). Research methods in education: An introduction. Boston: Ally and Bacon.

Wimmer, R.D., \& Dominick, J.R. (2000). Mass media research: An introduction. Belmont: Wadsworth Publishing Company.

www.ed.gov./pubs/edpubs.html

Turanlı, A.S. (2007). Gerçek bir ikilem: Ödev vermek ya da vermemek? Sosyal Bilimler Araştırmaları Dergisi, 1, 136-154.

Yıldırım, H. (2008, 15 Kasım). Ev ödevi nedir ne değildir? Akşam Gazetesi, s.12.

Yin, R. (2003). Case study research: Design and methods. Thousand Oaks: Sage.

Yuladır, C., \& Doğan, S. (2009). Fen ve teknoloji dersinde öğrencilerin ev ödevi performansını arttırmaya yönelik bir eylem araştırması. Çankaya Üniversitesi Fen-Edebiyat Fakültesi Dergisi, 12, 211-236. 